\title{
Study On HIV
}

\author{
Prabha $\mathrm{T}^{1^{*}}$, Abraham Jebaraj $\mathrm{S}^{2}$, Kiruthiga $\mathrm{G}^{3}$, V. Renuga ${ }^{4}$ \\ ${ }^{1}$ Professor, Department of Pharmaceutical Chemistry, Nandha College of Pharmacy, \\ Erode, Tamilnadu, Email: drtpappa@yahoo.com \\ ${ }^{2}$ Associate Professor, Department of Pharmaceutical Chemistry, Nandha College of \\ Pharmacy, Erode, Tamilnadu, Email: abrahamjebaraj@nandhapharmacy.org \\ ${ }^{3}$ Assistant Professor, Department of Pharmaceutical Chemistry, Nandha College of \\ Pharmacy, Erode, Tamilnadu, Email: kiruthiga@nandhapharmacy.org \\ ${ }^{4}$ Professor, Department of Child Health Nursing, Nandha College of Nursing, Erode, \\ Tamilnadu, Email: renugakg@gmail.com \\ ${ }^{*}$ Corresponding Author
}

\begin{abstract}
The goal of this study is to know about how T cells effects the Human Immuno Virus. T cells is a type of white blood cells which occurs at bone marrow. T cells severely disrupt the Immune system. Skin will also be effected through brusing by $\mathrm{T}$ cells. The killer $\mathrm{T}$ cells descry and destroy the infectious agent and the helper $T$ cells activates and alerts the pathogen. The white blood cells shield opposed to the threat in order to antibodies which are produced.
\end{abstract}

Keywords: T cell, HIV, CD4+, CD8+.

\section{Introduction}

Human Immuno virus is a ailment in which the unique medical notes of stern resourceful contaminations which provided the first signs concerning the basic virology and pathology, specifically that Human immune virus is basically an illness of the immune system which also consist of skin and muscle problems. Human immune virus poisons and removes $\mathrm{CD}^{+} \mathrm{T}$ cells that generally organize the adaptive $\mathrm{T}$ cell and B-cell retort to guard in contradiction of intracellular pathogens and intercellular pathogens. The immune flaw is instant and deep i.e., needing: At the period of critical contagion with the AIDS virus, classically more than half of the gut-associated $\mathrm{CD} 4^{+} \mathrm{T}$ cells are exhausted and distorted, parting a dented immune system to cope with a long-lasting inflammation.

A study of the $t$ cell purpose is for virus infested individuals exposed that the features of Human Immuno Virus immunopathogenesis that are completely not unstated. In spite of preliminary and the determined destruction to $\mathrm{CD}^{+} \mathrm{T}$ cells, and a tiniest quantity of noticeable Human Immuno Virus definite $\mathrm{CD}^{+} \mathrm{T}$ helper cells, the possibility and extent of $\mathrm{CD}^{+} \mathrm{T}$ cell reacts to healthy persons i.e., Human Immuno Virus in disease-ridden persons were intiated to be vibrant, with straight effecters role of such a scale that it might be willingly sensed in newly remote lymphocytes from exterior blood and brochoalveolar lavage in pretentious individuals with AIDS. Human Immuno Virus was previously identified to be an immunosuppressant disease, so far these $T$ cells were existing in large vigorous measure that they might be sensed by analyzes gauging the capability of newly inaccessible by bordering blood cells to the lyse autologous $B$ cells infested with recombining vaccine Human Immuno Virus routes or polypeptidic pounded goals. Furthermore, $\mathrm{CD}^{+} \mathrm{T}$ cells as of infested people are getting to prevent Human Immuno Virus duplication, undoubtedly viewing that these cells were handy at minimum in vitro, then contempt this, individuals stayed rolling to AIDS. 


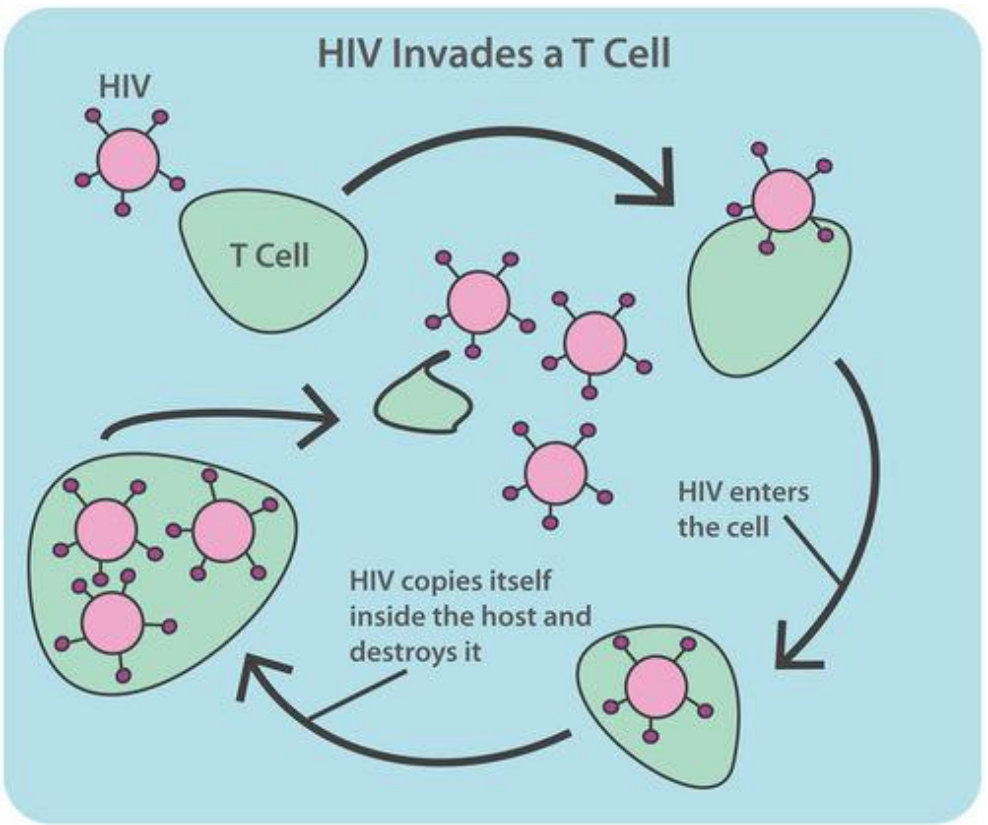

Fig. 1: Human Immuno Virus Invades a T Cell

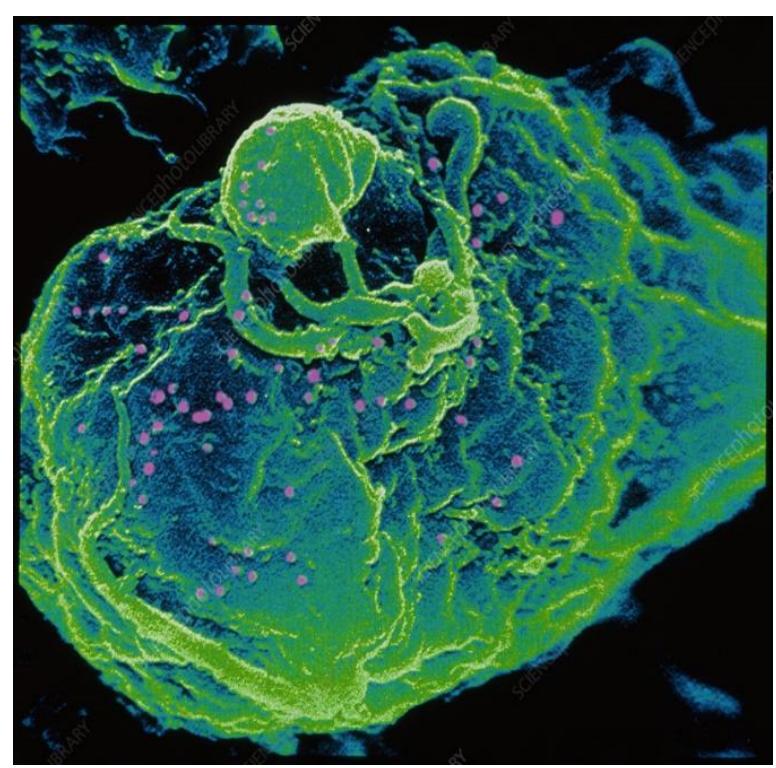

Fig.2: Effected T Cell

\section{CD4 ${ }^{+} \mathrm{T}$ Cells in Human Immuno Virus Infection}

Usually, in persons infested through Human Immuno Virus-1, the T-cell retorts are subjugated through $\mathrm{CD}^{+} \mathrm{T}$ cells. These are considerable tougher than $\mathrm{CD}^{+} \mathrm{T}$-cell retorts, which are dented by the disease. Assumed the significant part that $\mathrm{CD}^{+} \mathrm{T}$ cells take in continuing $\mathrm{CD}^{+} \mathrm{T}$ cell retorts, it is noteworthy that the final stand subsequently robust. In murine copies in which $C D 4^{+} T$ cells are worn-out whichever with antibody brew or hereditarily, $\mathrm{CD} 8^{+} \mathrm{T}$ cell retorts are significantly lessened. In Human Immuno Virus-1 contamination $\mathrm{CD}^{+} \mathrm{T}$ cells, however critically exhausted, are not totally vague, then irregularities in the growth of $\mathrm{CD}^{+} \mathrm{T}$ cell retorts might be steady with incomplete harm of $\mathrm{CD4}^{+} \mathrm{T}$ cell. $\mathrm{CD4}^{+} \mathrm{T}$-cell retorts might ultimate initial and at that time of waning to a comparatively small levels in the blood, in the presence of impairment to $\mathrm{CD}^{+} \mathrm{T}$ cells.
Primary research presented a absence of $\mathrm{CD} 4^{+} \mathrm{T}$ cell retorts, restrained by antigen stirred spread examines equally in primary and sub ordinate contamination. Though, originate by means of antigen moved cytokine construction, that HIV-specific T cells stayed existing at every phase of contagion, however in moderately little figures. A deficiency of IL-2 making by antigen- precise $C D 4^{+} T$ cells and $C D 8^{+} T$ cells might interpretation designed for the deceptive divergence among consequences by the binary analyses. In same initial contagion but, HIV-specific $\mathrm{CD}^{+} \mathrm{T}$ cells might be current in higher figures. exposed that once patient role remained preserved actual first by means of antiretroviral treatments, that robust $\mathrm{CD}^{+} \mathrm{T}$ cell retorts to HIV antigens might stay freed, as restrained by lymphocyte propagation analyze partake maintained this by screening sturdy $\mathrm{CD}^{+} \mathrm{T}$ cell retorts everywhere the period of ultimate viraemia, 
then these $\mathrm{T}$ cells are hastily misplaced as the contagion developments. This forfeiture might replicate the harm to the entire $\mathrm{CD}^{+} \mathrm{T}$ cell partition, but then it must be renowned that in further severe and long-lasting virus contagions . CD4 ${ }^{+} \mathrm{T}$ cell retorts might topmost initial and before decay to a moderately small close in the blood, in the nonappearance of impairment to $C D 4^{+} T$ cells . By the side of this opinion practically nonentity is identified nearby HIV-specific CD4 ${ }^{+} \mathrm{T}$ cell retorts in lymphoid muscles and the instinctive, undoubtedly wanted attention for upcoming trainings.

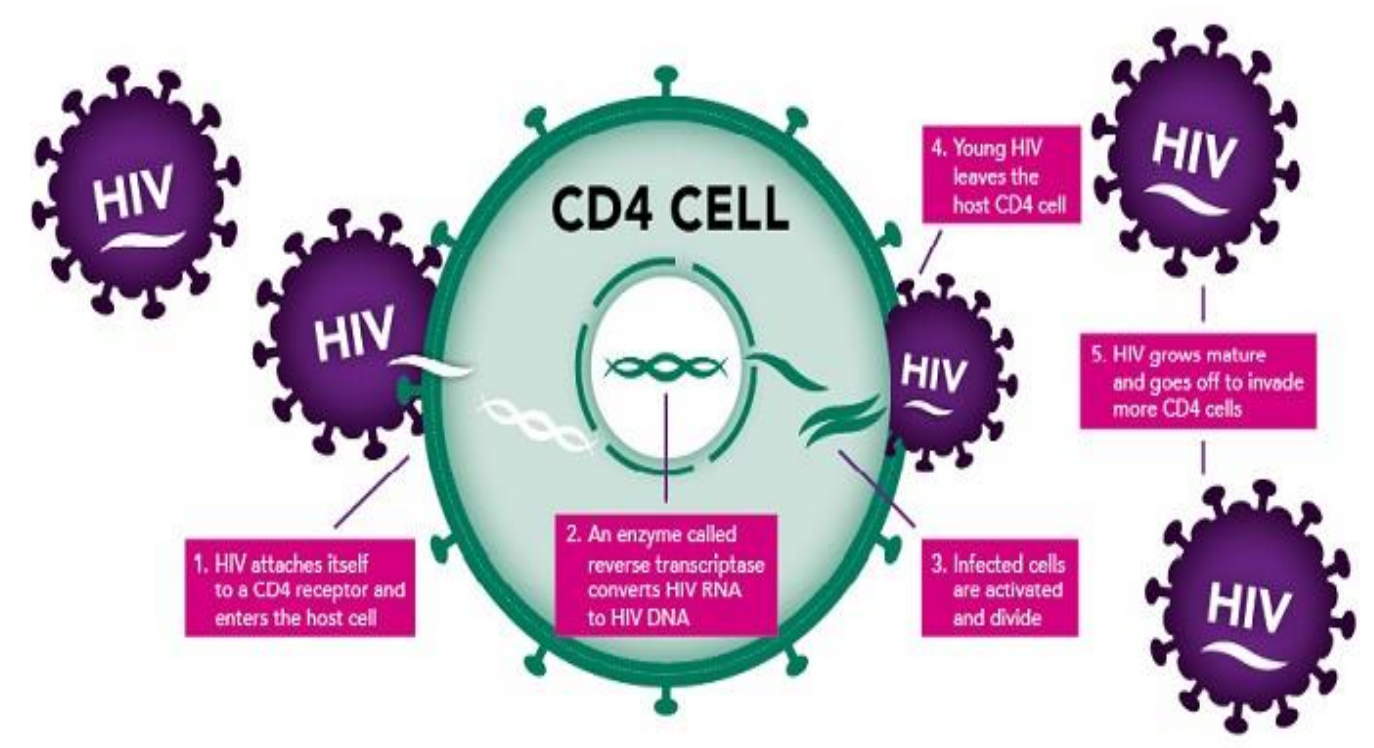

Fig. 3: CD4+ Cell

\section{$\mathrm{CD}^{+} \mathrm{T}$ Cells in Human Immuno Virus Infection}

The robust indication that Human Immuno Virus-1specific $\mathrm{CD}^{+} \mathrm{T}$ cells donate toward the controller of Human Immuno Virus-1 in the serious and long-lasting phases of contagion, it is significant to distinguish what $T$ cell purposes are accountable for this. Antiviral agent $\mathrm{CD}^{+} \mathrm{T}$ cells remained primarily predictable as $T$ cells that arbitrate lysis of virusinfested cells and are frequently cited to as cytotoxic $T$ lymphocytes. The issue is in the same way vibrant that every $\mathrm{CD}^{+} \mathrm{T}$ cells do not presentation altogether roles at all aeras. $C D 8^{+} \mathrm{T}$ cells retort quickly making interferon- $\gamma$ inside a rare period. $\mathrm{CD}^{+} \mathrm{T}$ cells may release perforin and granzymes in hours.

The comparative position of lytic machineries contrasted by cytokine or chemokine manufacture in anti-HIV movement is plentiful discoursed. In actual initial HIV-1 contagion $\mathrm{CD}^{+} \mathrm{T}$ cells quickly handpicked virus escape mutations, frequently choosing a original transformed to substitute all of the preceding virus people in a limited times. It is informal to describe this by effecter $\mathrm{CD}^{+} \mathrm{T}$ cells destroying HIVinfested mark cells they identify and thus reducing their life expectancy duration and volume to produce new virus elements. Though, original virus making might also be sunk by, for occurrence, B-chemokines concealed via $\mathrm{CD}^{+} \mathrm{T}$ cells dropping contagion of innovative aim cells by straight race for required to CCR5 otherwise by falling its countenance on the aim cells. Though, this might not cut the lifespan of the infested cells, which is what the accurate model, labeled by oblique. These lessons advise that lysis of infested cells is the maximum imperative antiviral agent purpose of the CD8 ${ }^{+} \mathrm{T}$ cells in severe contagion. This is reliable with the discovery that the T cells that hand-picked primary virus leak mutations are high perforin expressers while these primary $\mathrm{T}$ cells are somewhat partial in their look of cytokines and chemokines. This status of cytolysis in HIV-1 infection deviations with around extra virus contagions such as hepatitis B virus contagion where, in bodily replicas, perforin-deficient $T$ cells are extremely real as the key antiviral agent action is arbitrated nonlytic supporter by interferon- $\gamma$. And it is significant to communicate that here is information from in vivo study of SIV-infested macaques representative that reduction of $\mathrm{CD}^{+} \mathrm{T}$ cells two months and half year afterward contamination ensures no effect in a quantifiable alteration in the life of infested cells, signifying that straight assassination might not be not be the core apparatus of controller, at least in this model. 


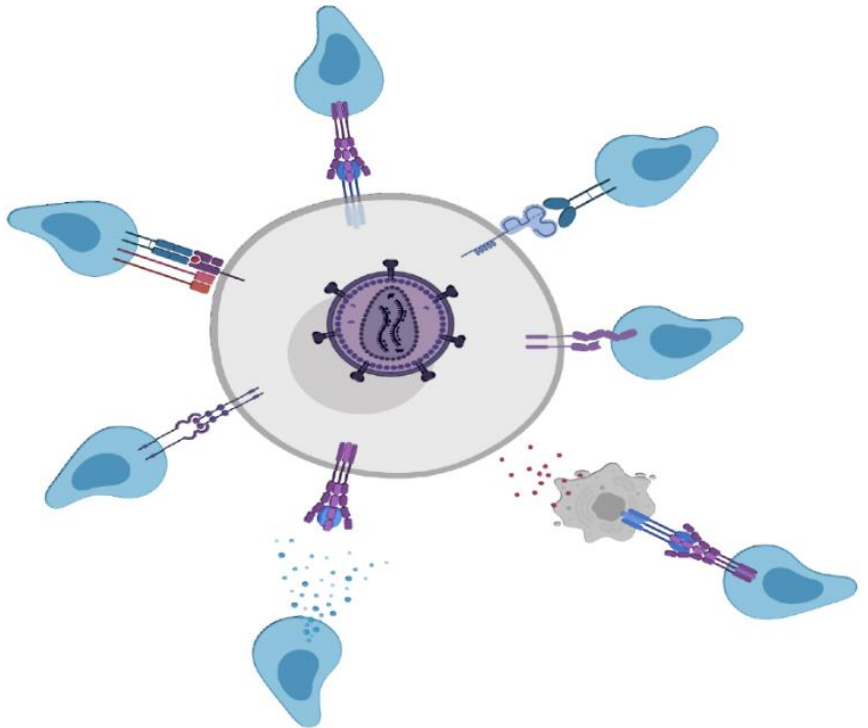

Fig.4: Viral Replication by $\mathrm{CD} 8^{+}$Cells

\section{T Cells Linked to Human Immuno Virus and Aids}

Human Immuno Virus go in its hereditary material interested in helper $\mathrm{T}$ cells to variety duplicates of the thing. Once this occurs, the helper T cells expire. This sternly interrupts the resistant retort. Small stages of helper $T$ cells means killer $T$ cells and additional white blood cells do not obtain as much data around pathogens in the form. As a effect, disease-causing microbes and germs increase with negligible recognition. After the volume of helper $T$ cells reduction below 200 cells $/ \mathrm{mm}$, a individual might obtain an AIDS analysis. Then health care specialists may similarly take interested in version other variable quantity such as complete white blood cell sum and the ratio of lymphocytes. AIDS is the maximum severe phase of Human Immuno Virus. When $\mathrm{a}$ individual accepts an AIDS analysis, their immune system is sternly cooperated, and they are at hazard for resourceful ailments. The subsistence amount short of action at this phase .

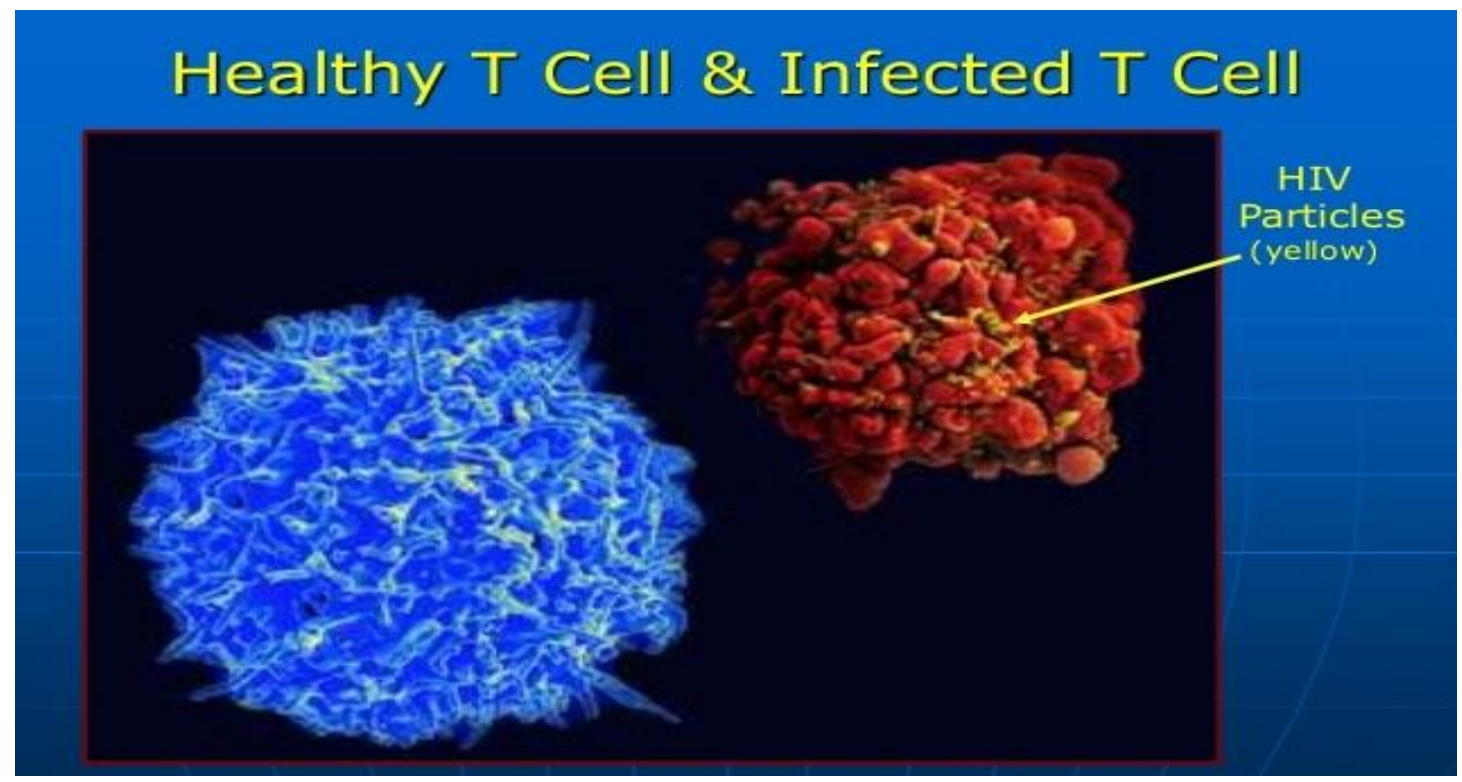

Fig.5: Healthy T Cell \& Infected T Cell

\section{Side Effects of T Cell}

- mild bruising: T Cell effect mainly on skin and is seen as small scars on the skin that causes mild bruising.

- Pain: T Cell effect on immune system that causes different pains at different organs.

- Dizziness: T Cell will be effected on nerves that causes woozy and unsteady.

- feeling faint: Feeling faint creates the sense of spinning the body and the surroundings that causes sudden fall. 


\section{Conclusion}

The progress of AIDS in whole HIV and infective contagion has the absurd eminence of existing a leisurely advanced pathogenetic course linking quick, extremely active mechanisms, a endlessly 'negotiated' equilibrium between direct and indirect effects on HIV replication that negotiate CD4+ memory T-cell existence or purpose and the capability of the host to substitute these misplaced cells and continue CD4+ memory T-cell populations by cell proliferation and differentiation. HIV Circulating subtypes for prevention and treatment completed and above the existing antiretroviral drugs.

\section{Reference}

1. ALTMAN D 1995. Statistical methods for medical researchers, Oxford, Oxford Press. ALTMAN D 1991. Practical statistics for medical research, London, Chapman and Hall.

2. ATUYAMBE, L., NEEMA, S., OTOLOK-TANGA, E., WAMUYU-MAINA, G., KASASA, S. \& WABWIRE-MANGEN, F. 2008. The effects of enhanced access to antiretroviral therapy: a qualitative study of community perceptions in Kampala city, Uganda. Afr Health Sci, 8, 13-9.

3. AVERT 2010. Universal access to AIDS treatment: targets and challenges, West Sussex, www.avert.org. Accessed 3rd April 2009.

4. BAGUMA, P. 1996. The traditional treatment of AIDS in Uganda: benefits and problems. Key issues and debates: traditional healers. Soc Afr SIDA, 4-6.

5. BAKEERA, S. K., PETZOLD, M., PARIYO, G. W., GALEA S., TOMSON, G. \& WAMALA, S. 2010. Community social capital and the use of health care services in Uganda. Journal of Public Health and Epidemiology 2, 189-198.
6. CHOMAT, A. M., WILSON, I. B., WANKE, C. A. SELVAKUMAR, A., JOHN, K. R. \& ISAAC, R. 2009. Knowledge, beliefs, and health care practices relating to treatment of HIV in Vellore, India. AIDS Patient Care STDS, 23, 477-84.

7. COETZEE, D., BOULLE, A., HILDEBRAND, K., ASSELMAN, V., VAN CUTSEM, G. \& GOEMAERE, E. 2004. Promoting adherence to antiretroviral therapy: the experience from a primary care setting in Khayelitsha, South Africa. AIDS, 18 Suppl 3, S27-31.

8. DAHLGREN L, EMMELIN M \& WINKVIST A 2004. Qualitative methodology for international public health, Umea, Umea University. MOH 2005a.

9. WHO antiretroviral therapy for HIV infection in adults and adolescents: recommendations for a public health approach - 2006 revision. Geneva, World Health Organization, 2006.

10. Nettles RE et al. Intermittent HIV-1 viremia (Blips) and drug resistance in patients receiving HAART. JAMA, 2005, 293(7):817-829.

11. Le Moing $\mathrm{V}$ et al. Predictors of long-term increase in CD4(+) cell counts in human immunodeficiency virusinfected patients receiving a protease inhibitorcontaining antiretroviral regimen. Journal of Infectious Diseases, 2002, 185(4):471-480.

12. Smith $\mathrm{CJ}$ et al. Factors influencing increases in CD4 cell counts of HIV-positive persons receiving long-term highly active antiretroviral therapy. Journal of Infectious Diseases, 2004, 190(10):1860- 1868.

13. Hunt PW et al. Continued CD4 cell count increases in HIV-infected adults experiencing 4 years of viral suppression on antiretroviral therapy. AIDS, 2003, 17:1907-1915.

14. Graber S et al. Clinical outcome of patients with HIV-1 infection according to immunological and virologic response after 6 months of highly active antiretroviral therapy. Annals of Internal Medicine, 2000, 133:401410. 